\title{
Electrical Tree Growth in Silicone Rubber/Organo-Montmorillonite Nanocomposites under AC Ramp Voltage
}

\author{
A. A. A. Jamila ${ }^{*}$, M. H. Ahmad ${ }^{b}$, Y. Z. Ariefb, M. Kamarola, M. Mariattia, N. Bashirb, M. A. M. Piah ${ }^{b}$ \\ aUniversiti Sains Malaysia, 14300 Nibong Tebal, Penang, Malaysia \\ bUniversiti Teknologi Malaysia, 81310 UTM Johor Bharu, Johor, Malaysia \\ *Corresponding author: abdulazimabdjamil@gmail.com
}

\section{Article history}

Received :15 February 2013

Received in revised form :

10 June 2013

Accepted :16 July 2013

\section{Graphical abstract}

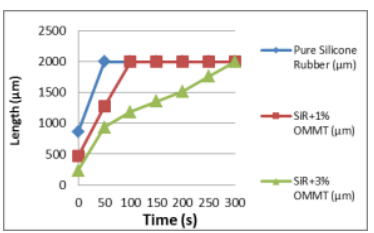

\begin{abstract}
This paper presents the results of the study on the electrical tree growth of organo-montmorillonite (OMMT) nanofillers in silicone rubber under ac ramp voltage of $0.5 \mathrm{kV}$ per second. This study investigates the ability of OMMT to retard the growth of electrical tree in silicone rubber. Samples of silicone rubber nanocomposites (two filled with $1 \%$ and 3\% OMMT respectfully while the third is unfilled silicone rubber), were used in this experimental study and the growth rate of the electrical tree and its length were observed in both samples. The result of this study has revealed that in the filled nanocomposite sample, the OMMT acts as barrier which slows down the growth rate of electrical tree. This makes OMMT a potential material to use as fillers in polymeric insulations for the purpose of retarding electrical tree growth.
\end{abstract}

Keywords: Nanodielectric; electrical treeing; nanofiller; nanocomposites; organo-montmorillonite

\begin{abstract}
Abstrak
Kertas kerja ini membentangkan hasil kajian pertumbuhan pokok elektrik pengisi nano, organomontmorilonit (OMMT) di dalam silikon getah di bawah voltan ac tanjakan $0.5 \mathrm{kV}$ sesaat. Kajian ini tertumpu untuk mengkaji keupayaan OMMT untuk merencat pertumbuhan pokok elektrik dalam getah silikon. Eksperimen dijalankan ke atas sampel silikon getah kosong serta silikon getah nanokomposit yang diisi dengan $1 \%$ dan $3 \%$ peratusan berat OMMT. Kadar pertumbuhan pokok elektrik serta panjang pokok telah diperhatikan pada setiap sampel. Hasil kajian ini mendedahkan bahawa OMMT berjaya melambatkan kadar pertumbuhan pokok elektrik. Oleh itu OMMT boleh menjadi bahan yang berpotensi untuk digunakan sebagai pengisi dalam penebatan polimer untuk merencatkan pertumbuhan pokok elektrik.
\end{abstract}

Kata kunci: Nanodielektrik; pokok elektrik; pengisi nano; nanokomposit; organo-montmorillonite

(C) 2013 Penerbit UTM Press. All rights reserved.

\subsection{INTRODUCTION}

Electrical treeing occurs in high voltage dielectric materials as a phenomenon that precedes electrical breakdown. Visibly, the electrical treeing progresses through a path in the dielectric in a form that resembles a miniature tree [1]. In their description of electrical treeing phenomena, D.W. Auckland and B.R. Varlow [2] likened the process to the visible tree-like structure damage that appears when energy is released in a gas-channel of about 1 micron. Electrical trees are usually found in the form of a branch, branch bush or bush shaped trees. When an electrical tree has initiated within the dielectric, it starts to grow and finally leads to the failure of the insulation [3-4].

There has been some existing methods to reduce growth of electrical tree in high voltage insulation and they include field grading, voltage stabilizer, filler, antioxidants, and ultraviolet stabilizers [5-6] until recently when nanofillers started attracting special attention from researchers due to their tremendous potential for a wide variety of applications; for example, nanofillers give polymers a densely packed structure thus acting as elementary barriers [7]. Nanofillers also tend to change the nature of the polymers because it offers a huge interfacial area [7]. However, it is important to note that if the nanofillers are not properly mixed with the polymer dielectric or nanocomposites, they could lead to having large portions of the matrix devoid of the nanofillers which may cause agglomeration.

In this research, electrical tree growth rate in silicone rubber (SiR) containing organo-montmorillonite (OMMT) was investigated to study the potential use of OMMT in silicone rubber nanocomposites which acts as barrier to retard the electrical tree growth. OMMT is a type of organoclay that has gain wide usage as rubber and plastic material due to its low cost and affordability [8]. Nanoclays exhibits excellent properties because of the fine phase dimension and special phase structure involved [9]. 


\subsection{EXPERIMENTAL}

\subsection{Material Used}

The silicone rubber used in this study is Sylgard 184 silicone Elastomer. It has a low viscosity and also dielectric strength, tensile strength and tears strength being $24 \mathrm{kV} / \mathrm{mm}, 6.2 \mathrm{MPa}$ and $2.7 \mathrm{kN} / \mathrm{m}$ respectively. The hardener used was Dimethyl, methylhydrogen siloxane. For preparing samples using this silicone rubber and the hardener, 100 parts by weight of the silicone rubber was mixed homegenously with 10 parts by weight of the hardener. This material was supplied by Farnell/ Element 14. The MMT was supplied by Nanocor Inc, USA. The OMMT (Nanomer 1.30P OMMT) is also supplied by Nanocor Inc, USA. The OMMT is montmorillonite clay modified with octadecylamine to reduce MMT's hydrophilic nature. This OMMT containing montmorillonite $(70 \mathrm{wt} \%)$ intercalated by octadecylamine $(30$ $\mathrm{wt} \%$ ). The mean dry particle size of the OMMT is in the range of 16-22 microns, respectively.

\subsection{Processing of Silicone Rubber/OMMT Nanocomposites}

The silicone rubber ( $\mathrm{SiR}$ ) Sylgard 184 was used in form of leaf-like specimen. The needle- plane electrode geometry was employed for initiation and propagation of electrical treeing. A tungsten wire having a diameter of $0.25 \mathrm{~mm}$ was used. The needle tip formed by electrolytic polishing with aid of $\mathrm{NaOH}$ solution with its tip radius and tip angle being $5 \mu \mathrm{m}$ and 30 degrees respectively. Each needle's tip that has been created was examined, measured and documented by a camera-equipped microscope before the polymers casting. The gap distance between the needle tip and the plane electrode was adjusted to $2 \mathrm{~mm}$.

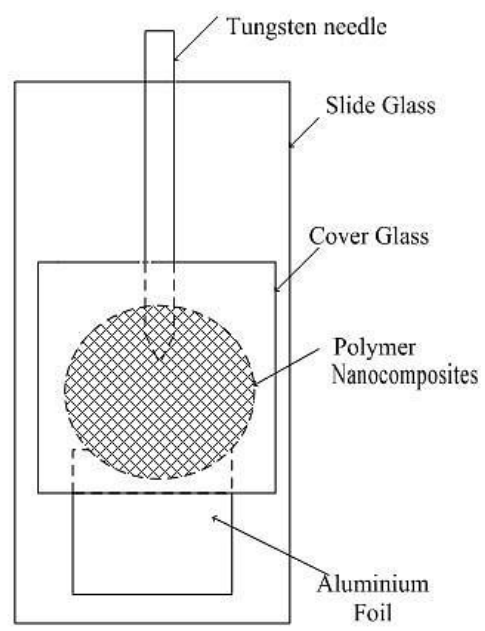

Figure 1 Leaf-like specimen for electrical treeing experiment

After the completion of the needle electrode, 16 to 22 micron mean dry particle size of organo-montmorillonite (OMMT) filler was heated at $105^{\circ} \mathrm{C}$ for 2 hours using conventional vacuum oven to remove moisture. After preconditioning the OMMT, it was mixed with the silicone rubber in 1 and 3 weight percent (wt \%) using hotplates magnetic stirrer at $80^{\circ} \mathrm{C}$ for 2 hours at $125 \mathrm{rpm}$. To obtain homogeneous dispersion of nanofiller, silicone rubber nanocompsoites dispersed using 705 Sonic Dismembrator for 1 hour. Then, the silicone rubber nanocomposites were mixed with its hardener (ratio 10:1) for 15 minutes at $125 \mathrm{rpm}$ using a hotplates magnetic stirrer at room temperature. The nanocomposite was cast onto the electrode gap to cover the whole gap between the electrodes. The specimen was cured at $100{ }^{\circ} \mathrm{C}$ for 45 minutes. The specimen was prepared in form of leaf-like as shown in Figure 1.

\subsection{Test Sample Preparation}

Online monitoring system was developed in this work to study the electrical treeing. The monitoring system consists of a stereomicroscope, a personal computer, and a charge-coupled device (CCD) camera as shown in Figure 2. The based system consisted of an Olympus SZX16 Research Stereomicroscope equipped with auxiliary DP 26 Olympus Xcam-Alpha CCD camera with $115 x$ magnification capability. The given magnification level was sufficient to capture magnified images of electrical tree initiation. The purpose of this arrangement was to observe the inception of electrical treeing optically at room temperature.

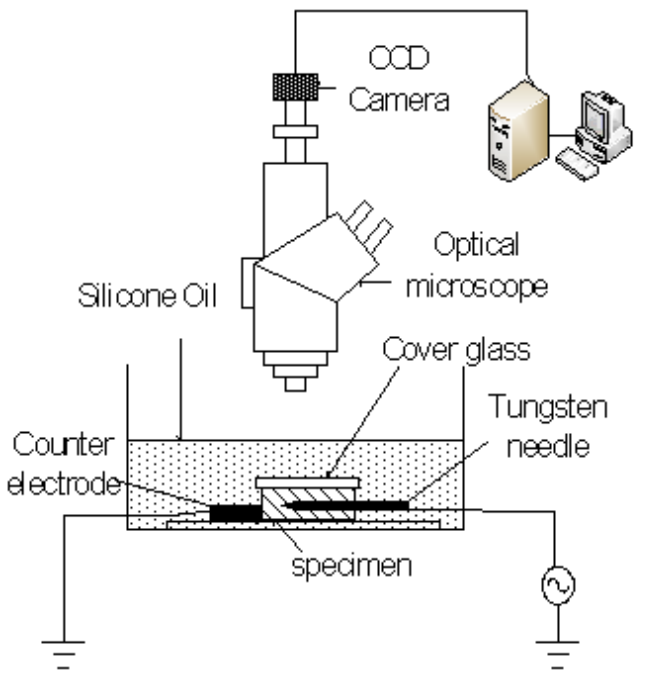

Figure 2 Set-up of camera-equipped online monitoring system for electrical treeing studies schematic diagram

The experiments were conducted to measure the tree inception voltage and tree breakdown voltage by applying ac ramp voltage with increasing rate $0.5 \mathrm{kV}$ per second at power frequency. The samples were placed inside an acrylic cell containing silicone oil to prevent surface flashover. Tree inception was continuously observed through a specifically developed system. The microscope and the CCD camera were interfaced with a computer. The images of electrical treeing at test voltage were captured and the tree inception voltage recorded once the tree length had exceeded 10 $\mu \mathrm{m}$ [19]. During electrical tree inception, the real time images of electrical tree were captured using CCD camera mounted at stereomicroscope with the aided of cellsens digital imaging software.

\subsection{RESULTS AND DISCUSSION}

Table 1 show the experimental results of tree propagation length against time for unfilled silicone rubber, silicone rubber filled with $1 \%$ of OMMT and silicone rubber filled with $3 \%$ of OMMT. The experimental result in Figure 3 shows a significant effect the nanofiller on the growth rate of electrical tree propagation length. The growth of electrical treeing in silicone rubber filled with 3\% OMMT is relatively slower compared to unfilled silicone rubber and silicone rubber filled with $1 \%$ OMMT. The growth of electrical tree in unfilled silicone rubber bridged the gap within 50 seconds, 
compared to the samples filled with $1 \%$ and $3 \%$ OMMT which bridged the gap within 100 and 300 second, respectively.

Table 1 Experimental result of tree propagation length

\begin{tabular}{cccc}
\hline Time $(\mathbf{s})$ & Unfilled Silicone Rubber $(\boldsymbol{\mu m})$ & SiR+1\% OMMT $(\boldsymbol{\mu m})$ & SiR+3\% OMMT $(\boldsymbol{\mu m})$ \\
\hline 0 & 856.67 & 467.58 & 234.02 \\
50 & 2000 & 1272.22 & 937.01 \\
100 & 2000 & 2000 & 1182.68 \\
150 & 2000 & 2000 & 1358.5 \\
200 & 2000 & 2000 & 1516.7 \\
250 & 2000 & 2000 & 1760.08 \\
300 & 2000 & 2000 & 2000
\end{tabular}

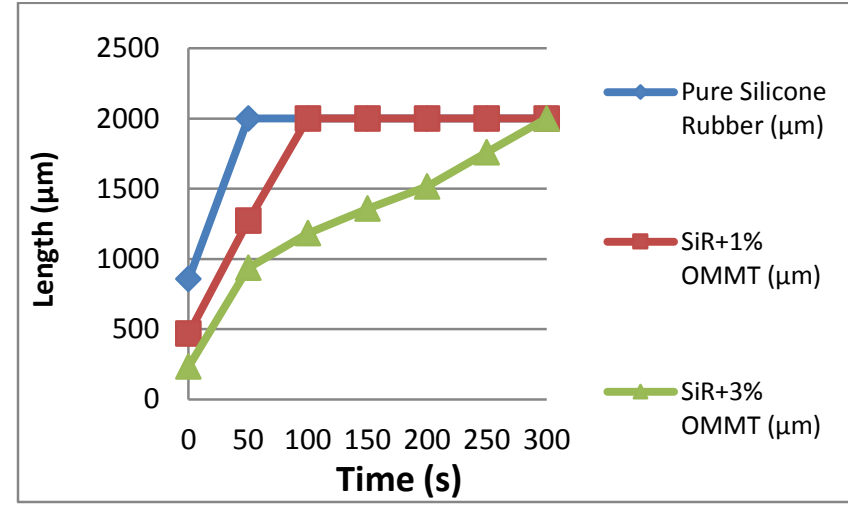

Figure 3 Growth rate of tree propagation length

The result obviously indicates that the presence of nanofiller in polymer composite helped to slowed down the electrical tree growth. The OMMT nanofiller tend to modify the silicone rubber matrices as it offers huge interfacial area. The increase in the interfacial area inhibits the tree growth because the nanofiller reduced the interfiller distance. Immobilized polymer increase with compaction of nanofiller and consequently the interaction between the loosely bound polymer and the nanofillers is reduced [5]. The existing of nanofiller in the silicone rubber hindered the growth of electrical tree, thereby increasing the time for breakdown. Figure 4 shows the photograph of the electrical tree captured by the microscope at different stages.

\subsection{CONCLUSION}

OMMT with one and three weight percent (\%wt) has been added to silicone rubber in order to study its ability to retard the growth of electrical treeing. The following conclusions can be made from this study:

1. The growth rate of electrical treeing in silicone rubber filled with OMMT nanofiller was relatively slower compared with unfilled silicone rubber. This indicates that the OMMT acted as barrier and hence can retard the growth of electrical treeing.

2. The rate of length toward the time of electrical treeing growth, $\mathrm{dL} / \mathrm{dt}$ for silicone rubber with $3 \%$ of OMMT is $14.06 \mu \mathrm{ms}^{-1}$ compared to silicone rubber with $1 \%$ of OMMT, $16.09 \mu \mathrm{ms}^{-1}$ and unfilled silicone rubber, $22.87 \mu \mathrm{ms}^{-1}$. From this rate of length toward the time of electrical treeing growth, it clearly shows that the increasing addition of OMMT into silicone rubber helped to retarded the electrical treeing.

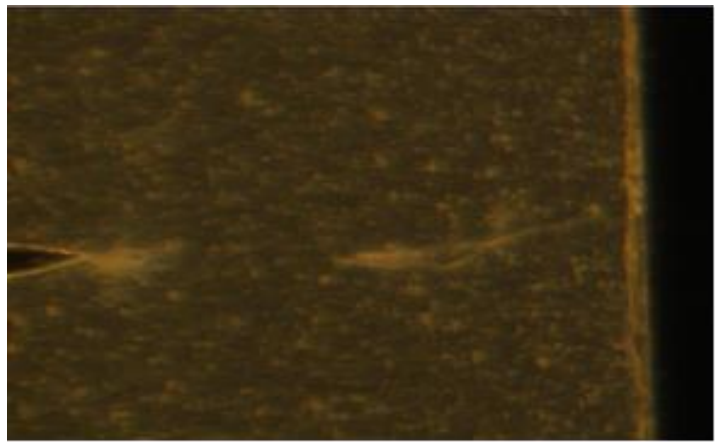

(a) Electrical tree inception stage

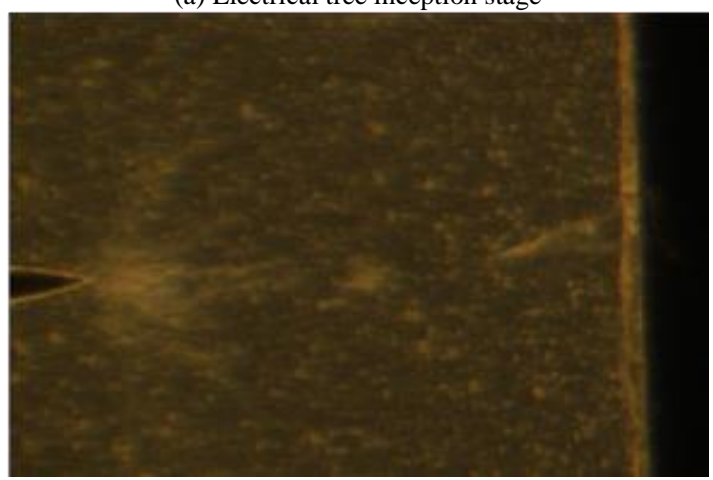

(b) Electrical tree propagation stage

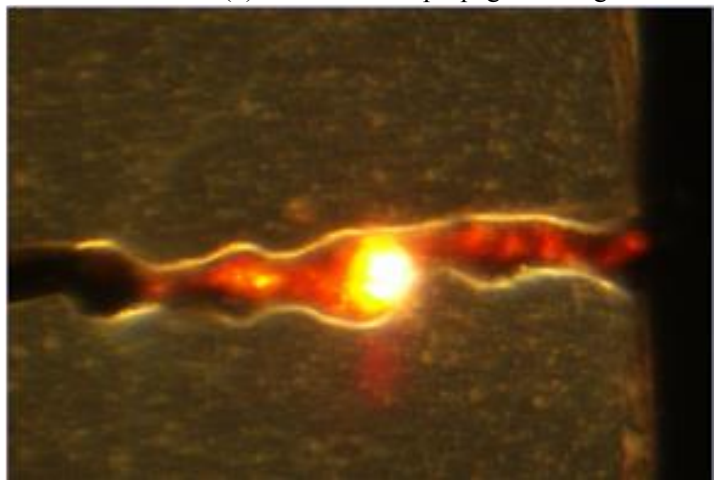

(c) Electrical tree breakdown stage

Figure 4 Photograph of electrical tree growth 


\section{Acknowledgement}

The author wishes to thank Universiti Teknologi Malaysia, Universiti Sains Malaysia and Ministry of High Education (MOHE) for financial support. This research project was carried out under vote $05 \mathrm{~J} 07,03 \mathrm{~J} 15$ and $00 \mathrm{H} 19$

\section{References}

[1] Al-Arainy, A. A., Qureshi, M. I., \& Malik, N. H. 2005. Fundamentals of High Voltage Engineering. King Saud Press.

[2] Auckland, D. W., \& Varlow, B. R. 1995. Electrical Treeing in Solid Polymeric Insulation. Engineering Science and Education Journal. 4(1): 11.

[3] Ahmad, M. H., Ahmad, H., Bashir, N., Dolmat, M. F., Arief, Y. Z., Malek, Z. A., \& Jamil, A. A. A. 2012. Effects of Oil Palm Empty Frui Bunch Filler on Electrical Tree Propagation in Epoxy Resin. 2012 International Conference on High Voltage Engineering and Application 203-206.
[4] Jamil, A. A. A., Kamarol, M., Mariatti, M., Bashir, N., Ahmad, M. H., Arief, Y. Z., \& Muhamad, N. A. 2012. Organo-montmorillonite as an Electrical Treeing Retardant for Polymeric Insulating Materials. 2012 IEEE International Conference on Condition Monitoring and Diagnosis 237-140.

[5] Ahmad, M. H., Ahmad, H., Bashir, N., Jamil, A. A. A., Piah, M. A. M., Malek, Z. A., \& Dodd, S. J. 201). Electrical Treeing in Silicone Rubber/organo-montmorillonite. 2012 Annual Report Conference on Electrical Insulation and Dielectric Phenomena. 898-901.

[6] Abdul-Malek, Z., Azzin, A. M., Arief, Y. Z. Aulia, Lau, K. Y., Jaafar, M. 2011. Influence of Nanosilica Filler Content in LDPE Composites on Partial Discharge Characteristics. Gaodianya Jishu/High Voltage Engineering. 37(11): 2629-2635.

[7] Danikas, M., \& Tanaka, T. 2009. Nanocomposites-A Review of Electrical Treeing and Breakdown. IEEE Electrical Insulation Magazine. 25(4): 19-25.

[8] Arroyo, M., López-Manchado, M. \& Herrero, B. 2003. OrganoMontmorillonite as Substitute of Carbon Black in Natural Rubber Compounds. Polymer. 44(8): 2447-2453.

[9] Gu, Z., Song, G., Liu, W., Yang, S., \& Gao, J.(2010. Structure and Properties of Hydrogenated Nitrile Rubber/organo-Montmorillonite Nanocomposites. Clays and Clay Minerals. 58(1): 72-78. 